\title{
Effect of grassland degradation on soil quality and soil biotic community in a semi-arid temperate steppe
}

\author{
Xu Han ${ }^{1,2+}$, Yuhui $\mathrm{Li}^{1,2+}$, Xiaofang Du ${ }^{1,2}$, Yingbin $\mathrm{Li}^{1}$, Zhengwen Wang ${ }^{1}$, Siwei Jiang ${ }^{1}$ and Qi Li ${ }^{1^{*}}$ (D)
}

\begin{abstract}
Grasslands provide a number of ecosystem services for human society. Degradation of grasslands results in the loss of biodiversity and leads to the deterioration of ecosystem functions. In order to accurately assess the influence of grassland degradation on belowground ecosystems, we conducted experiments on a temperate steppe with different levels of degradation and investigated the influence of degradation on soil quality and soil biotic communities. Our results showed that grassland degradation significantly decreased soil quality, with lower values of soil quality index (SQI) observed in the degraded grassland than the meadow steppe and the grassland from the forest-steppe ecotone. Changes in the SQI along the grassland degradation gradient were positively correlated with soil carbon stock and the aboveground biomass, and negatively correlated with the root shoot ratio. Nematode trophic diversity and the ratio of fungal to bacterial PLFA were lower in the degraded grassland than the grassland from the forest-steppe ecotone. The dissimilarities in soil microbial and nematode community composition increased with the changes in soil quality index. Our results indicate that soil quality index based on the minimum data sets could effectively assess the influence of grassland degradation on soil biodiversity and ecosystem function. In order to effectively restore degraded grasslands, the key contributors to the soil quality, such as soil carbon, should be taken on priority basis for revitalizing the soil biodiversity and ecosystem function.
\end{abstract}

Keywords: Soil quality, Soil biodiversity, Grassland degradation, Soil nematode community

\section{Introduction}

Grasslands are the largest terrestrial ecosystems on earth and it covers about $40 \%$ of the earth's surface, providing a large number of ecosystem services to human society ( Hu et al. 2016; Lyu et al. 2020). Grasslands in China account for $11.8 \%$ of the global grassland area and play important roles in livestock production and environmental conservation (Dong et al. 2012; Ren et al. 2008). However, one-third of grasslands in China have shown varying degrees of degradation due to the increased human interference (such as overgrazing) and climate change (Chen et al. 2014; Qi et al. 2012). Although numerous measures have been taken to restore the degraded grasslands (Guo et al. 2018; Zhang et al.

\footnotetext{
* Correspondence: liq@iae.ac.cn

${ }^{+} \mathrm{Xu}$ Han and Yuhui Li contributed equally to this work.

${ }^{1}$ Erguna Forest-Steppe Ecotone Research Station, Institute of Applied

Ecology, Chinese Academy of Sciences, Shenyang 110016, China

Full list of author information is available at the end of the article
}

2019), one of the major issues is how to accurately assess the influence of grassland degradation (Zhang et al. 2019). Grassland degradation causes the loss of biodiversity and leads to ecosystem function degradation (Gang et al. 2014; Lyu et al. 2020; Raiesi and Salek-Gilani 2020). Therefore, elucidating the mechanisms that influence grassland degradation on the changes in soil quality and biotic communities is important so as to develop effective solutions to restore the degraded grassland ecosystems (Lal 2015; Raiesi and Salek-Gilani 2020).

Soil quality is considered as the capacity of the soil to perform ecosystem functions (Karlen et al. 2003), which can be assessed by measuring the changes of soil physical, and chemical properties induced by different land managements (Andrews et al. 2002a; Bongiorno 2020). Recently, soil quality assessments have received more and more attention to accurately evaluate the impact of land-use changes on

\section{Springer Open}

(อ The Author(s). 2020 Open Access This article is licensed under a Creative Commons Attribution 4.0 International License, which permits use, sharing, adaptation, distribution and reproduction in any medium or format, as long as you give appropriate credit to the original author(s) and the source, provide a link to the Creative Commons licence, and indicate if changes were made. The images or other third party material in this article are included in the article's Creative Commons licence, unless indicated otherwise in a credit line to the material. If material is not included in the article's Creative Commons licence and your intended use is not permitted by statutory regulation or exceeds the permitted use, you will need to obtain permission directly from the copyright holder. To view a copy of this licence, visit http://creativecommons.org/licenses/by/4.0/. 
degradation and sustainable land management (Guo et al. 2018; Raiesi and Salek-Gilani 2020). Using soil quality index (SQI), Li et al. (2013) have detected the extent of rangeland degradation after land-use changes and Zhang et al. (2019) found that vegetation restoration has improved the soil quality in the karst regions of southwest China. Guo et al. (2018) also found that the SQI values increased with the increasing of restoration ages on the loess hill region of China. Researches in grassland have shown that management intensification has an adverse impact on soil and plant characteristics (Askari and Holden 2014). For example, overgrazing not only reduces the biomass of palatable species (Gaitán et al. 2018) but also changes root shoot ratio and soil bulk density (Hendricks et al. 2005; Yan et al. 2020), which in turn leads to a reduction in soil carbon and nitrogen pools ( $\mathrm{Hu}$ et al. 2016; Yan et al. 2020). Thus, soil quality index is the summarizing of these interdependent properties by choosing the best representative indicators which can comprehensively evaluate the effects of grassland degradation on soil quality and ecosystem function (Zhang et al. 2019).

Changes in soil quality can directly or indirectly influence the belowground biota and the associated ecological functions. In order to assess soil quality induced by grassland degradation more precisely, soil biotic communities should also be considered (Zhang et al. 2019). Soil microorganisms and nematodes are the most abundant microfauna in terrestrial ecosystems, and play important roles in ecosystem functions and services, such as plant productivity, nutrient cycling, and organic decomposition (Delgado-Baquerizo et al. 2020). Grassland degradation can affect soil biotic communities via changes in vegetation composition and soil characteristics (Chen et al. 2013; Wang et al. 2018). Chen et al. (2013) found that the influence of overgrazing on soil microbes led to a negative effect on soil nematode communities in a field experiment in Inner Mongolia. Thus, grassland degradation will affect the composition of soil biotic communities and ultimately influence the ecological processes they involved in. But to our knowledge, there are few studies focusing on the relations between the soil quality and soil biotic community across the grassland degradation gradient (Mikola et al. 2009).

Therefore, in order to study the influence of grassland degradation on soil quality and its relations with soil biotic communities, we conducted field experiments on the grasslands with different levels of degradations in Hulunbuir of Inner Mongolia. The degraded grassland in this study belonged to the meadow steppe which was subjected to human disturbance and overgrazing, leading to the reduction of productivity and ecosystem services (Xu et al. 2019). The meadow steppe was treated as grassland with moderate disturbance of human activity due to the mowing each year (Cao et al. 2019; Yan et al. 2016). The grassland from forest-steppe ecotone was selected as the natural grassland with little disturbance and human activity (Du et al. 2020). We hypothesized that grassland degradation will have negative influences on soil quality and soil biotic communities, with lower SQI index and diversity of soil biotic community observed in the degraded grassland compared with the meadow steppe and grassland from the forest-steppe ecotone. Since the soil microbial and nematode communities play an important role in carbon sequestration and nutrient cycling, changes in soil quality due to grassland degradation should be closely related to the changes in biotic communities along the grassland degradation gradient.

\section{Materials and methods}

\section{Study site and design}

The study site was located near Erguna Forest-Steppe Ecotone Research Station of the Chinese Academy of Sciences $\left(50^{\circ} 10^{\prime} 46.1^{\prime \prime} \mathrm{N}, 119^{\circ} 22^{\prime}\right.$ 56.4' E) in the Hulunbuir grassland. The mean annual precipitation in this area is approximately $363 \mathrm{~mm}$, and the mean annual temperature is $-2.45^{\circ} \mathrm{C}$. The soil type is chernozem in World Reference Base for Soil Resources (WRB) (IUSS Working Group WRB 2006; Yang et al. 2019).

During the summer of 2017, degraded grassland (DG), meadow steppe (MG), and the grassland from foreststeppe ecotone (TG) were selected across the grassland degradation gradient. Degraded grassland was previously used as a horse ranch with the plant community dominated by Carex duriuscula, Cleistogenes squarrosa, Potentilla acaulis, Artemisia frigida, and Serratula centauroides (Lü et al. 2017). Meadow steppe has the plant community dominated by Carex duriuscula, Leymus chinensis, Cleistogenes squarrosa, Filifolium sibiricum, and Stipa capillata (Lin et al. 2017). Grassland from the forest-steppe ecotone had the richest plant community dominated by Carex duriuscula, Galium verum, Pulsatilla chinensis, Thalictrum aquilegifolium, Sedum aizoon, Paeonia lactiflora, Artemisia scoparia, Leymus chinensis, Schizonepeta multifidi, and Sanguisorba officinalis (Zhu et al. 2010).

\section{Plant sampling and analysis}

For each grassland type, four replicates $\left(100 \times 100 \mathrm{~m}^{2}\right.$ for each) were selected with a distance of about $1 \mathrm{~km}$ for each replicate. To test plant community composition, average height, species richness, and coverage of each plant species were recorded in a $1 \mathrm{~m} \times 1 \mathrm{~m}$ quadrat in each plot. Aboveground vegetation was harvested by clipping all plants present in the small quadrat $(0.4 \mathrm{~m} \times$ $0.4 \mathrm{~m}$ ) within each $1 \mathrm{~m} \times 1 \mathrm{~m}$ quadrat. For measuring belowground biomass, one soil core with a diameter of $8 \mathrm{~cm}$ was collected from each small quadrat at $15 \mathrm{~cm}$ depth, then we used a $2 \mathrm{~mm}$ sieve to collect root 
carefully. All aboveground and belowground plant tissues were oven dried at $60^{\circ} \mathrm{C}$ to constant weight to obtain the aboveground and belowground biomass.

\section{Soil sampling and analysis}

Soil samples were collected using soil cores $(2.5 \mathrm{~cm})$ at $0-15 \mathrm{~cm}$ depth, and then mixed together as a composite sample for each replicate. After gentle homogenization and removal of roots, half of the fresh soil samples were stored in individual plastic bags and kept at $4{ }^{\circ} \mathrm{C}$ for soil biotic analysis. The other soil samples were sieved through a $2 \mathrm{~mm}$ mesh and air dried to analyze soil properties. For measuring bulk density, soil cores were collected using the cutting ring $\left(100 \mathrm{~cm}^{3}\right)$ from each plot. Soil moisture and bulk density were determined by oven-drying subsamples at $105^{\circ} \mathrm{C}$ for $24 \mathrm{~h}$. A 1:2.5 soil: water was used for measuring soil $\mathrm{pH}$ by a glass electrode (Kim 1998). Total carbon (TC) and total nitrogen (TN) contents in each sample were determined using a TruSpec CN Elemental Analyzer (Leco Corporation, USA). Total phosphorus (TP) was determined by the method of molybdenum-antimony colorimetric using a spectrophotometer (Shimadzu Inc., Kyoto).

\section{PLFA analysis}

Soil microbial community was tested by phospholipid fatty acid (PLFA) analysis (Certini et al. 2004). Lipids were extracted from $4 \mathrm{~g}$ of freeze-dried soil using a chloroformmethanol-citrate buffer mixture (1:2:0.8), and the phospholipids were separated from neutral lipids and glycolipids on a SPE tube (Supelco Inc., Bellefonte). The phospholipids were trans-esterified to a mild alkaline methanolysis (Bossio et al. 1998) and the resulting fatty acid methyl esters were extracted in hexane and dried under $\mathrm{N}_{2}$. Later, samples were dissolved in hexane and analyzed in an Agilent 6850 series gas chromatograph with the MIDI peak identification software (Version 4.5; MIDI Inc., Newark).

\section{Nematode community analysis}

Soil nematodes were extracted from $100 \mathrm{~g}$ of fresh soil according to a modified cotton-wool filter method (Oostenbrink 1960; Townshend 1963). Nematode populations were expressed as the individuals per $100 \mathrm{~g}$ dry soil and at least 100 individuals from each sample were identified to genus level (Ahmad and Jairjpuri 2010; Bongers 1994; Li et al. 2017). Nematodes were assigned to the following trophic groups according to their feeding habits and life-history characteristics: (i) bacterivores; (ii) fungivores; (iii) omnivore-predators, and (iv) plant parasites (Yeates et al. 1993). Trophic diversity, Shannon index, structure index, and enrichment index of the nematode community were calculated according to Ferris et al. (2001).

\section{Soil quality index calculation}

Soil quality index (SQI) was calculated by selection of minimum data set (MDS) that best representative indicators for soil functions. Using principal component analysis (PCA), principal components (PCs) with eigenvalues $>1$ and explained $>5 \%$ of total variation were assumed to represent the soil quality for MDS (Andrews et al. 2002a; Brejda et al. 2000). Within each PC, the highly loaded variables within $10 \%$ of the highest loading were selected as key indicators (Andrews et al. 2002a). When more than one variable was retained within a PC, linear correlations were calculated. If the correlation coefficient between variables was more than 0.60 , the variable was considered redundant and eliminated from the MDS (Andrews et al. 2002a, 2002b).

We then used the following sigmoidal type curve to normalize and score the MDS indicators (Andrews et al. 2002a; Brejda et al. 2000).

$$
\mathrm{NL}-\mathrm{SF}(Y)=\frac{a}{\left(1+\left(\frac{x}{x_{0}}\right)^{b}\right)}
$$

Where NL-SF $(Y)$ is the nonlinear score of each indicator ranging from 0 to $1, a$ is the maximum value ( $a=$ $1), x$ is the value of the selected indicator, and $x_{0}$ is the mean value of each indicator. $b$ is the slope of the equation and is set as -2.5 for "more is better" functions and 2.5 for "less is better" functions.

The final step for the soil quality assessment combined the selected indicators into an overall SQI using the following weighted additive equation (Andrews et al. 2002a, 2002b).

$$
\mathrm{SQI}=\sum_{i=1}^{n} W_{i} S_{i}
$$

Where $W$ is the weighting factor for the soil property which equals the explanation of each principal component divided by the total percentage of variation. $S$ is a nonlinear (NL-SQI) score. Then SQI is considered to be the overall assessment of soil quality, with higher values meaning better soil quality.

\section{Statistical analysis}

Before analysis, nematode abundances were $\ln (x+1)$ transformed, other data that do not meet the assumptions of normality and homogeneity were also logtransformed. A mixed linear model (nlme) was used to test the differences across the degradation gradient with grassland type as a fixed factor and replicates as random factors. A Tukey HSD test was used for multiple comparisons. Microbial and nematode community compositions were visualized by PCA analysis. We calculated the beta diversity of microbial and nematode community 
composition using the Bray-Curtis dissimilarity (Bray and Curtis 1957). Mantel tests (Spearman's rank correlation) were conducted to test the relationships between soil quality index (Euclidean distance) and soil biotic community (Bray-Curtis distance). Further, we calculated the Pearson correlation coefficient between soil quality index and soil abiotic characteristics.

\section{Results}

\section{Effect of grassland degradation on soil quality index}

Grassland degradation significantly influenced plant biomass (Table 1), with lower aboveground biomass observed in the degraded grassland (DG) than that in meadow steppe (MG) and the grassland from foreststeppe ecotone (TG), but the root biomass did not differ among three grassland types (Table 1). The root shoot ratio was higher in DG than that in MG and TG. Grassland degradation also significantly affected soil nutrient contents, with higher contents of total carbon, nitrogen, and phosphorus observed in TG than in MG and DG (Table 1).

The principal component analysis based on the soil physicochemical parameters showed that the eigenvalues of the first two PCs were $>1$ and explained $78.3 \%$ of the total variance (Table 2). Total carbon and root shoot ratio were highly weighted indicators retained in PC1 and PC2 (Table 2). Soil total carbon had the highest contribution (74\%) to the SQI values followed by root shoot ratio (26\%). The values of SQI were significantly lower in DG (0.16-0.39) than those in MG (0.33-0.48) and TG (0.63-0.85). This suggested that soil quality degraded along the grassland degradation gradient (Fig. 1).
Effect of grassland degradation on soil biotic community Grassland degradation also affected soil microbial community, with higher contents of total and fungal PLFAs observed in MG and TG in comparison with DG (Fig. 2). The ratio of fungal to bacterial PLFA (F/B) was significantly lower in DG than that in MG and TG (Fig. 2). Grasslands with different levels of degradation were obviously discriminated in the PCA ordination plot. Specif-

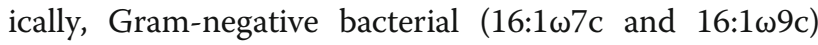

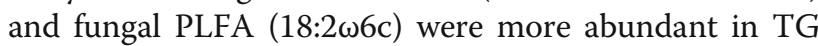
than in MG and DG (Fig. S2). Similar patterns were also found in the soil nematode community. The abundances of total nematodes and omnivores-predators were higher in TG than in MG and DG (Fig. 3). Ecological indices of the nematode community showed the same trends with higher values of trophic diversity, Shannon index and enrichment index observed in the TG than in MG and DG (Fig. 3).

\section{Relations between soil quality and soil biotic and abiotic characteristics}

Soil quality index was positively correlated with the aboveground biomass and soil carbon stock, and negatively correlated with the root shoot ratio (Fig. 4). Positive correlations were found between SQI and the fungal and AMF PLFAs, and the F/B ratio. Similar patterns were also found between SQI and the number of omnivores-predators and nematode ecological indices (Fig. 5). Further, the distance of the soil quality index was positively correlated with the beta diversity of microbial and nematode communities (Fig. 6). Changes in soil quality could explain $19 \%$ and $15 \%$ of the variations in microbial and nematode community, and the tested environmental parameters explained $48 \%$ of the total

Table 1 Basic soil and plant characteristics along the grassland degradation gradient

\begin{tabular}{llll}
\hline & DG & MG & TG \\
\hline Soil environment & & & $55.45 \pm 7.77 \mathrm{a}$ \\
Soil moisture $(\%)$ & $19.92 \pm 0.52 \mathrm{c}$ & $35.23 \pm 5.29 \mathrm{~b}$ & $0.75 \pm 0.06 \mathrm{c}$ \\
Bulk density $\left(\mathrm{g} / \mathrm{cm}^{3}\right)$ & $1.16 \pm 0.01 \mathrm{a}$ & $1.03 \pm 0.05 \mathrm{~b}$ & $6.21 \pm 0.1 \mathrm{c}$ \\
$\mathrm{pH}$ & $6.67 \pm 0.05 \mathrm{~b}$ & $6.93 \pm 0.05 \mathrm{a}$ & $75.45 \pm 2.77 \mathrm{a}$ \\
Soil nutrient & & & $5.94 \pm 0.22 \mathrm{a}$ \\
Total C $(\mathrm{g} / \mathrm{kg})$ & $29.30 \pm 0.83 \mathrm{~b}$ & $31.33 \pm 0.59 \mathrm{~b}$ & $0.97 \pm 0.04 \mathrm{a}$ \\
Total N $(\mathrm{g} / \mathrm{kg})$ & $2.92 \pm 0.07 \mathrm{~b}$ & $2.79 \pm 0.04 \mathrm{~b}$ & \\
Total P $(\mathrm{g} / \mathrm{kg})$ & $0.46 \pm 0.01 \mathrm{~b}$ & $0.46 \pm 0.02 \mathrm{~b}$ & $411.72 \pm 20.11 \mathrm{a}$ \\
Plant & & & $4447.15 \pm 994.38$ \\
Aboveground biomass $\left(\mathrm{g} / \mathrm{m}^{2}\right)$ & $143.71 \pm 23.29 \mathrm{c}$ & $292.16 \pm 26.46 \mathrm{~b}$ & $11.24 \pm 2.71 \mathrm{~b}$ \\
Belowground biomass $\left(\mathrm{g} / \mathrm{m}^{2}\right)$ & $2866.81 \pm 297.47$ & $2570.06 \pm 151.84$ & $9.26 \pm 0.7 \mathrm{~b}$ \\
Root shoot ratio & $24.83 \pm 3.65 \mathrm{a}$ & & \\
\hline
\end{tabular}

DG degraded grassland, MG meadow steppe, TG the grassland from the forest-steppe ecotone

Means with different letters in the same row indicate significant differences at $P<0.05$

Data are shown as mean \pm SE 
Table 2 Principal component analysis of soil quality indicators

\begin{tabular}{lll}
\hline Principal component & PC1 & PC2 \\
\hline Eigenvalues & 5.22 & 1.83 \\
Variance (\%) & 57.96 & 20.34 \\
Cumulative (\%) & 57.96 & 78.3 \\
Aboveground biomass & 0.33 & 0.27 \\
Belowground biomass & 0.18 & -0.53 \\
Root shoot ratio & -0.14 & $-\mathbf{0 . 6 3}$ \\
Water content & 0.32 & 0.15 \\
Bulk density & -0.35 & -0.27 \\
pH & -0.31 & 0.37 \\
Total C & $\mathbf{0 . 4 3}$ & -0.08 \\
Total N & 0.42 & -0.12 \\
Total P & 0.4 & -0.06 \\
\hline
\end{tabular}

Notes: Bold factors are retained in the minimum data set (MDS) $\mathrm{PC} 1$ and $\mathrm{PC2}$ indicated the first and second principal component

variations in soil biotic community composition (Table S1).

\section{Discussion}

\section{Effects of grassland degradation on soil quality}

Grassland degradation induced by overgrazing destroys the ecological environment, which had negative influences on the plant and soil communities (Wu et al. 2014). In our study, soil total carbon was selected as an effective indicator of soil quality. Soil total carbon is a key factor affected by grazing (Hu et al. 2016; Mcsherry and Ritchie 2013) which is the most frequently used trait in soil quality calculation (Askari and Holden 2014). The reduced carbon inputs from above- and belowground

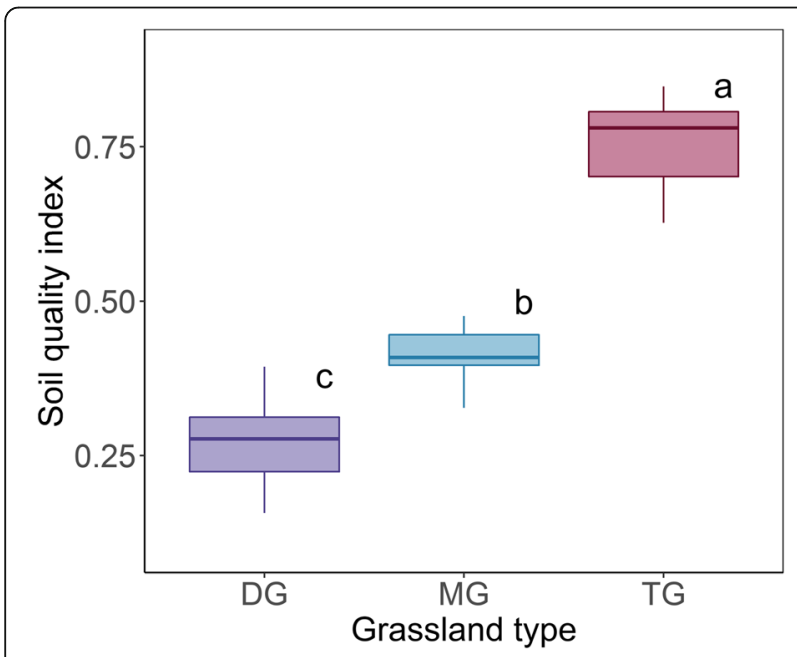

Fig. 1 Soil quality index across the grassland degradation gradient. $\mathrm{DG}$, degraded grassland; $\mathrm{MG}$, meadow steppe; $\mathrm{TG}$, grassland from the forest-steppe ecotone. Bars with different letters indicate significant difference at $P<0.05$. Error bars represent \pm SE biomass in the degraded grassland may be the main drivers for the lower content of total carbon (Shen et al. 2020; Wilson et al. 2018; Yan et al. 2020). In the meadow steppe, we also found that soil carbon stock was lower than the TG (Fig. S3), which may be due to that mowing reduced the accumulation of litter and then decreased the carbon input into soil (Chen et al. 2019; Li et al. 2020). The negative impacts of grassland degradation on aboveground biomass and non-significant effects on belowground biomass in this study resulted in an increase in root shoot ratio, which can change the plant biomass allocation (Gao et al. 2008). The root shoot ratio was also used as an indicator of MDS, which was higher in degraded grassland in comparison with that in the meadow steppe and grassland from transition ecotone. The increase in root shoot ratio is also related to the decrease of vegetation coverage and plant diversity (Fig. S1), which means soil conditions are not suitable for vegetation growth (He and Richards 2015; $\mathrm{Li}$ et al. 2018). In turn, these changes in soil $C$ and root shoot ratio can limit the growth of plant and soil biotic communities, and then decrease the soil quality index indirectly.

Effects of grassland degradation on soil biotic community In our study, grassland degradation also significantly affected the soil biotic community. Along the gradient of grassland degradation, the highest abundance and diversity of soil nematodes and microorganisms were found in the TG. As a natural grassland with little disturbance, grassland from the forest-steppe ecotone has higher soil moisture and the most frequent material, energy, and biological flow (Sottile et al. 2015), which may result in higher biodiversity in TG than MG and DG. By contrast, degraded grassland has the lowest abundance and diversity of microorganisms. This may be because excessive human interference, such as overgrazing and the excavation of wild herbs. In the degraded grassland ecosystems, grazing animals can affect soil microorganisms directly through feces and trampling (Mahaming et al. 2009), or indirectly through selectively feeding plants to change soil carbon input (Penner and Frank 2019). All these factors can damage soil structure, and form an environment that is not conducive to soil microbe growth (Zhou et al. 2019). Arbuscular mycorrhizal fungi (AMF) are closely related with plant species and biological fertility (Begum et al. 2019; Coutinho et al. 2019), so the reduction of plant communities may result in the decrease of AMF in degraded grassland. Studies have found that fungi can stabilize the input of soil resources (Waring et al. 2013), and promote soil organic carbon accumulation (Six et al. 2006; Strickland and Rousk 2010). In the present study, the lowest values of fungal PLFA and F/B ratio in degraded grassland may indicate that the soil 

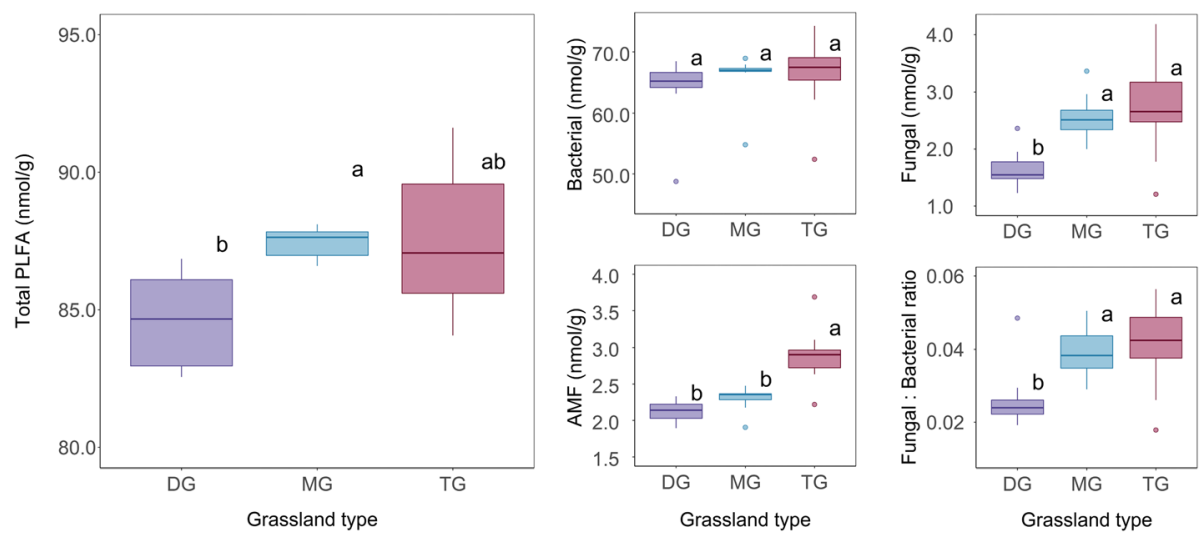

Fig. 2 Changes in soil microbial communities across the grassland degradation gradient. DG, degraded grassland; MG, meadow steppe; TG, grassland from the forest-steppe ecotone. Bars with different letters indicate significant difference at $P<0.05$. Error bars represent \pm SE

environment is not sustainable for carbon accumulation and plant growth due to the overgrazing.

Nematodes are one of the most abundant and diverse biological groups in the soil, occupying multiple trophic levels in the soil food web (Thakur et al. 2014; Xiong et al. 2020). The relatively lower abundance and diversity of the nematode community in degraded grassland suggest that grassland degradation has a negative influence on soil nematode community. In degraded grassland ecosystem, continuous overgrazing significantly reduces the diversity of the plant communities, which has an adverse effect on soil nematode communities. On one hand, overgrazing will reduce above- and belowground abundance and diversity due to soil resource depletion (Qi et al. 2011). On the other hand, grazing also increases soil bulk density and reduces air circulation by livestock trampling, which may lead to a decline in omnivorous nematodes in degraded grassland. In addition, a decrease in omnivores-predators may reduce the topdown regulation to the soil food web, resulting in an increase in plant-parasite nematodes in degraded grasslands, and then negatively influence the plant growth and nutrient cycling (Ruan et al. 2012).

\section{Relationship between soil quality index and soil biota}

In agreement with our second hypothesis, we found that the dissimilarities in microbial and nematode community composition were closely related to the changes in soil quality, which explained $15-20 \%$ of variations in soil biotic communities. Our results suggest that changes in soil quality can alter the composition of soil microbial and nematode communities. Since soil biological properties are sensitive to environmental changes and provide important information about soil functions (Stone et al. 2016), our results reinforce that grassland degradation induced by overgrazing can negatively affect soil quality and soil biodiversity. Although soil biodiversity is important for maintaining ecosystem function and stability, it was often ignored in previous grassland degradation assessments due to its complexity in analysis and
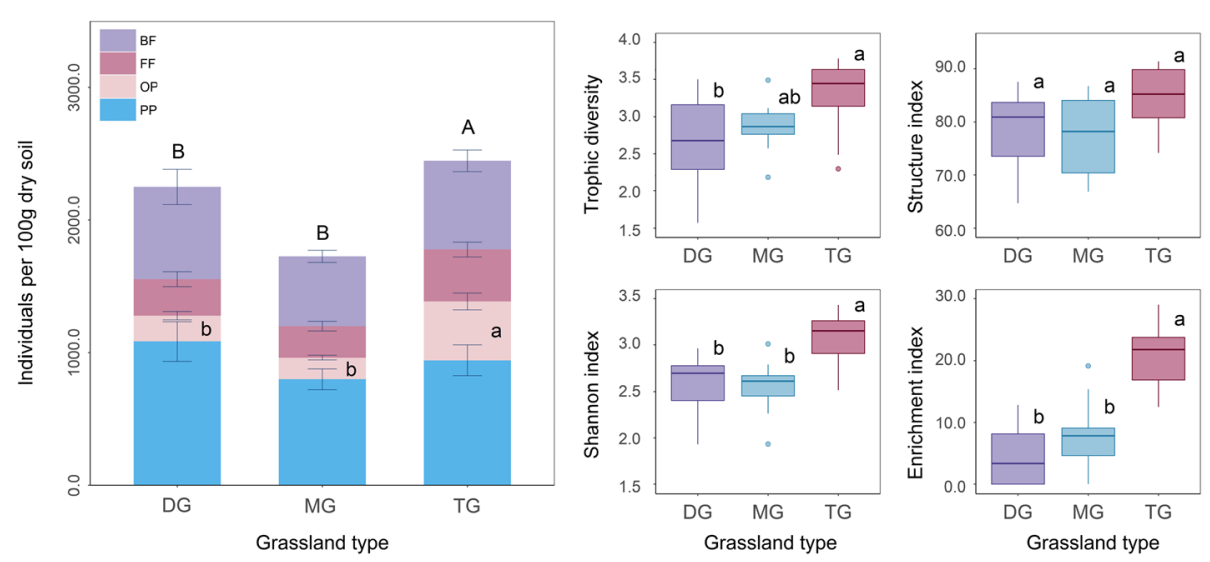

Fig. 3 Changes in soil nematode communities across the grassland degradation gradient. DG, degraded grassland; MG, meadow steppe; TG, grassland from the forest-steppe ecotone. Bars with different letters indicate significant difference at $P<0.05$. Error bars represent $\pm \mathrm{SE}$ 

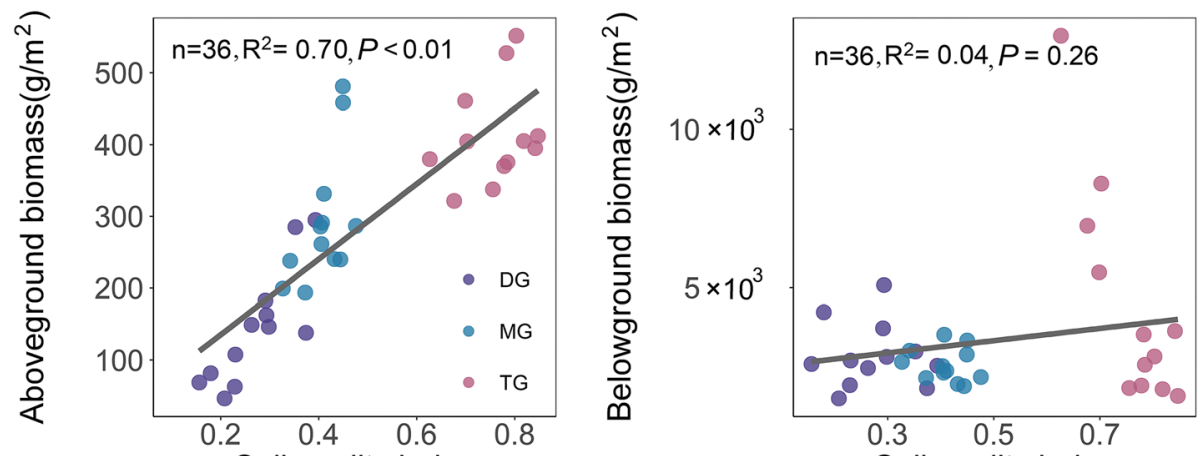

Soil quality index
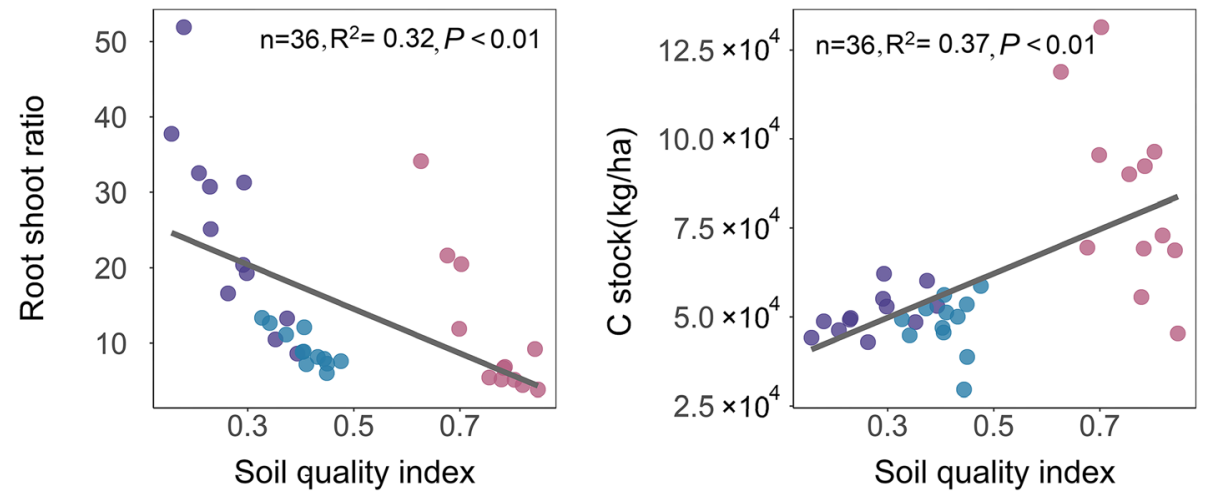

Fig. 4 Correlations between soil quality index and selected soil and plant characteristics

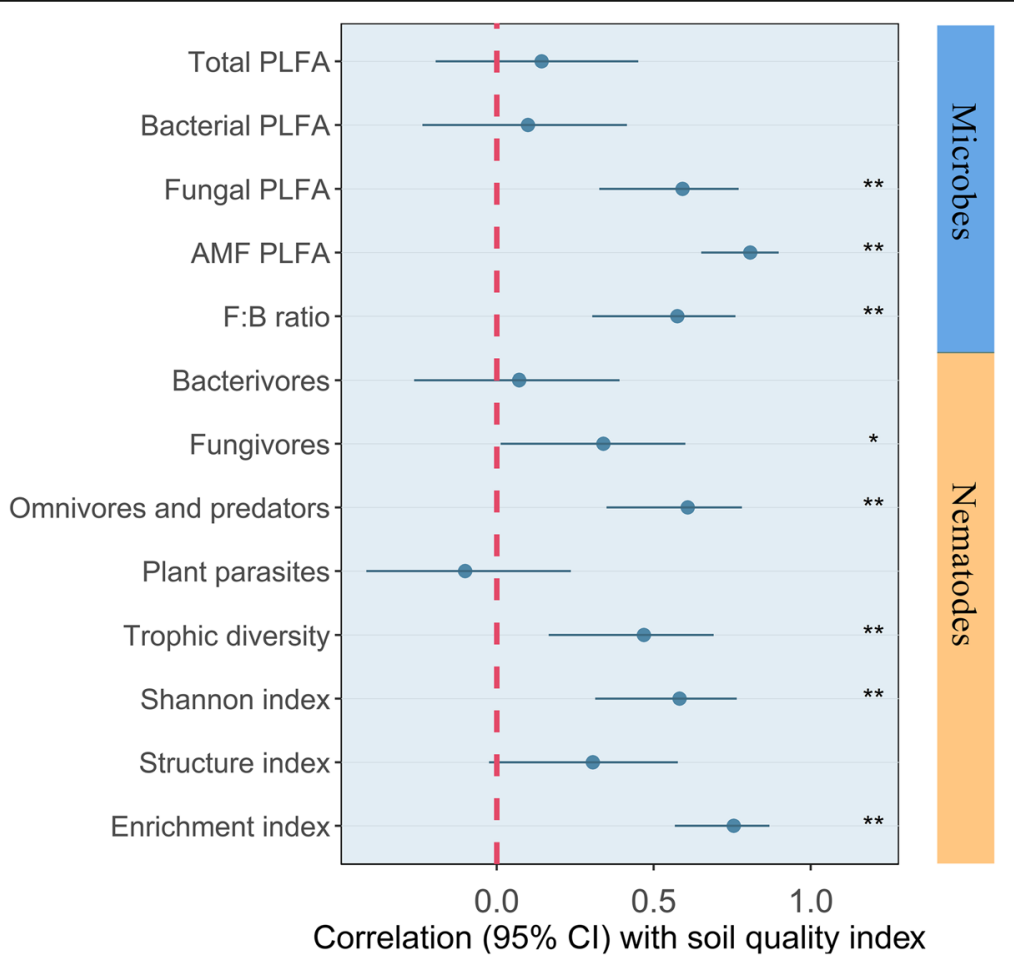

Fig. 5 Pearson correlation analysis between soil quality index and indices of soil microbial and nematode communities 

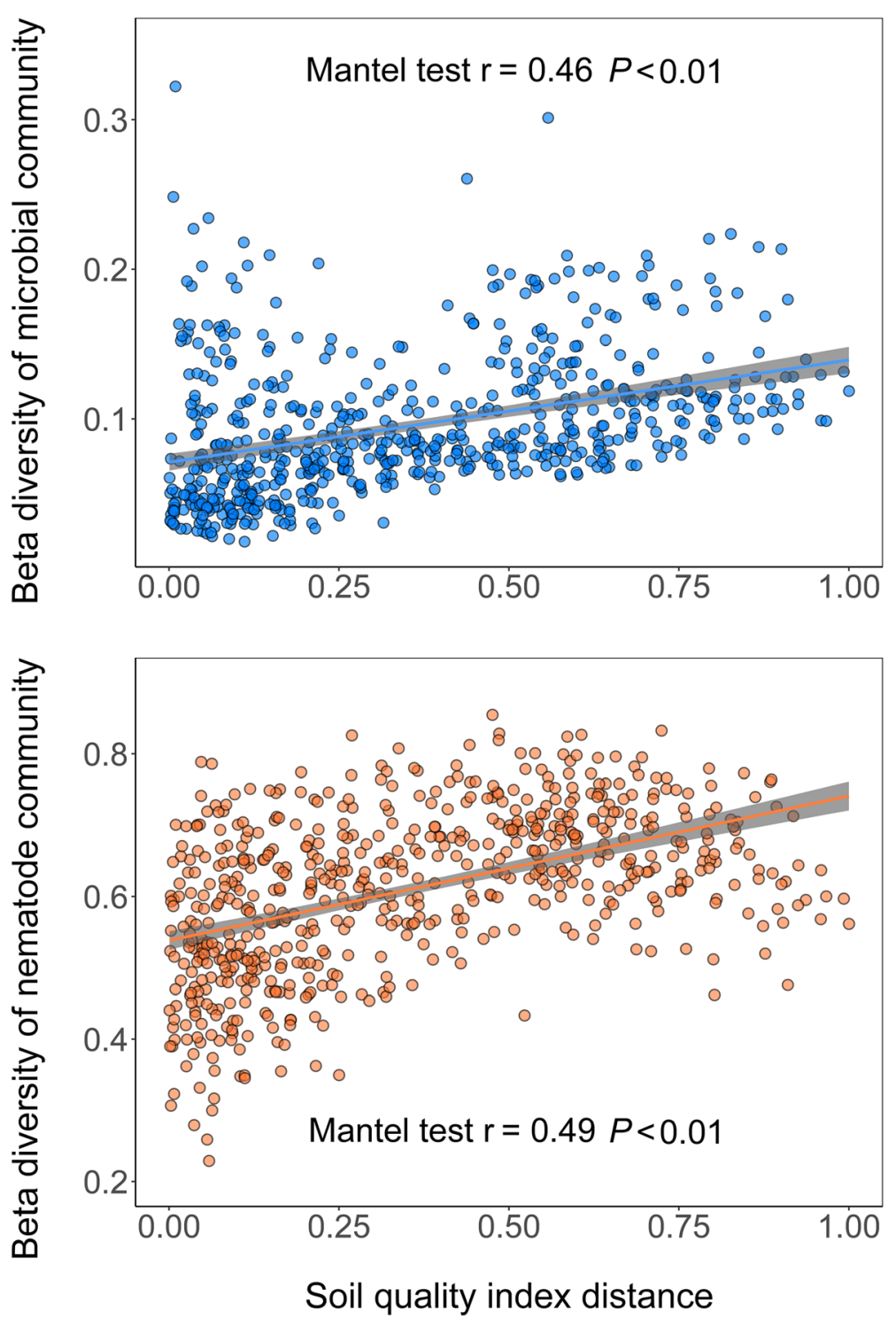

Fig. 6 Correlation between the beta diversity of soil microbial/nematode communities (Bray-Curtis distance) and the soil quality index distance (Euclidean distance) along the grassland degradation gradient (based on $n=36$ soil samples)

sampling procedures. With the rapid developments in molecular techniques and bioinformatics, the diversity and composition of soil biota can be measured in a rapid and cost-effective manner ( $\mathrm{Du}$ et al. 2020). Therefore, including biological properties in soil quality evaluations can provide better assessment of the degree of grassland degradation and their effects on soil ecological functions.

\section{Conclusion}

Our research reveals that changes in soil quality induced by grassland degradation are closely related with soil carbon, the root shoot ratio, and soil microbial and nematode communities. In order to accurately assess the degradation, changes in both soil quality and the soil biotic communities should be considered. As one of the key contributors to soil quality, soil carbon restoration should be a priority in order to better restore the ecosystem functions and biodiversity in semi-arid temperate grasslands.

\section{Supplementary Information}

The online version contains supplementary material available at https://doi. org/10.1186/s13717-020-00256-3.

Additional file 1: Figure S1. Shannon index and evenness index of plant community along the grassland degradation gradient. DG, degraded grassland; MG, meadow steppe; TG, grassland from the foreststeppe ecotone. Bars with different letters indicate significant difference at $P<0.05$. Figure S2. PCA analysis of soil microbial community (left) 
and nematode community (right). DG, degraded grassland; MG, meadow steppe; TG, grassland from the forest-steppe ecotone. Means \pm SE are shown. Figure S3. Soil C stock across grassland degradation gradient. DG, degraded grassland; $M G$, meadow steppe; $T G$, grassland from the forest-steppe ecotone. Bars with different letters indicate significant difference at $P<0.05$. Means \pm SE are shown. Table S1. Results of redundancy analysis (RDA) of soil and plant characteristics on microbial (PLFA) and nematode community composition.

\section{Abbreviations}

DG: Degraded grassland; MG: Meadow steppe; TG: The grassland from the forest-steppe ecotone; AMF: Arbuscular mycorrhizal fungi;

PLFA: Phospholipid fatty acid; SQI: Soil quality index; PCA: Principal component analysis; MDS: Minimum data set

\section{Acknowledgements}

The authors acknowledge the staff (Jianzhong Sun, Yuanyuan Li, and Chao Zhang) of the Erguna Forest-Steppe Ecotone Research Station for their assistance with sample collection.

\section{Authors' contributions}

Qi Li and Zhengwen Wang designed the experiment. Xu Han analyzed the data and wrote the draft together with Yuhui Li. Yuhui Li and Siwei Jiang analyzed the soil and plant properties of all the samples. Qi Li, Yingbin Li, and Xiaofang Du approved the final manuscript. The author(s) read and approved the final manuscript.

\section{Funding}

This study was supported by the National Key Research and Development Program of China (2016YFC0500602) and the National Natural Science Foundation of China (No. 41877047).

\section{Availability of data and materials}

The datasets used and/or analyzed during the current study are available from the corresponding author on reasonable request.

\section{Ethics approval and consent to participate}

Not applicable.

\section{Consent for publication}

Not applicable.

\section{Competing interests}

The authors declare that they have no competing interests.

\section{Author details}

${ }^{1}$ Erguna Forest-Steppe Ecotone Research Station, Institute of Applied Ecology, Chinese Academy of Sciences, Shenyang 110016, China. ${ }^{2}$ University of Chinese Academy of Sciences, Beijing 100049, China.

\section{Received: 29 April 2020 Accepted: 1 September 2020}

\section{Published online: 11 November 2020}

\section{References}

Ahmad W, Jairjpuri MS (2010) Mononchida: the predaceous nematodes. Nematology Monographs and Perspectives. Brill, Boston

Andrews SS, Karlen DL, Mitchell JP (2002a) A comparison of soil quality indexing methods for vegetable production systems in Northern California. Agr Ecosyst Environ 90(1):25-45. https://doi.org/10.1016/S0167-8809(01)00174-8

Andrews SS, Mitchell JP, Mancinelli R, Karlen DL, Hartz TK, Horwath WR, Pettygrove GS, Scow KM, Munk DS (2002b) On-farm assessment of soil quality in California's central valley. Agron J 94(1):12-23. https://doi.org/10. 2134/agronj2002.0012

Askari MS, Holden NM (2014) Indices for quantitative evaluation of soil quality under grassland management. Geoderma 230-231:131-142. https://doi.org/ 10.1016/j.geoderma.2014.04.019

Begum N, Qin C, Ahanger MA, Raza S, Khan Ml, Ashraf M, Ahmed N, Zhang LX (2019) Role of arbuscular mycorrhizal fungi in plant growth regulation: implications in abiotic stress tolerance. Front Plant Sci 10:1068. https://doi. org/10.3389/fpls.2019.01068
Bongers T (1994) De Nematoden van Nederland. In: Vormgeving en technische realisatie. Uitgeverij Pirola, Schoorl, Netherlands

Bongiorno G (2020) Novel soil quality indicators for the evaluation of agricultural management practices: a biological perspective. Front Agr Sci Eng 7:257274. https://doi.org/10.15302/J-FASE-2020323

Bossio DA, Scow KM, Gunapala N, Graham KJ (1998) Determinants of soil microbial communities: effects of agricultural management, season, and soil type on phospholipid fatty acid profiles. Microb Ecol 36(1):1-12. https://doi. org/10.1007/s002489900087

Bray JR, Curtis JT (1957) An ordination of the upland forest communities of southern Wisconsin. Ecol Monogr 27(4):326-349

Brejda JJ, Moorman TB, Karlen DL, Dao TH (2000) Identification of regional soil quality factors and indicators: I. Central and southern high plains. Soil Sci Soc Am J 64(6):2115-2124. https://doi.org/10.2136/sssaj2000.6462115x

Cao J, Yan RR, Chen XY, Wang X, Yu Q, Zhang YL, Ning C, Hou LL, Zhang YJ, Xin XP (2019) Grazing affects the ecological stoichiometry of the plant-soilmicrobe system on the Hulunber steppe, China. Sustainability 11(19):5226. https://doi.org/10.3390/su11195226

Certini G, Campbell CD, Edwards AC (2004) Rock fragments in soil support a different microbial community from the fine earth. Soil Biol Biochem 36(7): 1119-1128. https://doi.org/10.1016/j.soilbio.2004.02.022

Chen BX, Zhang XZ, Tao J, Wu JS, Wang JS, Shi PL, Zhang YJ, Yu CQ (2014) The impact of climate change and anthropogenic activities on alpine grassland over the Qinghai-Tibet Plateau. Agr Forest Meteorol 189-190:11-18. https:// doi.org/10.1016/j.agrformet.2014.01.002

Chen DM, Xing W, Lan ZC, Saleem M, Wu Y, Hu SJ, Bai YF (2019) Direct and indirect effects of nitrogen enrichment on soil organisms and carbon and nitrogen mineralization in a semi-arid grassland. Funct Ecol 33(1):175-187. https://doi.org/10.1111/1365-2435.13226

Chen DM, Zheng SX, Shan YM, Taube F, Bai YF (2013) Vertebrate herbivoreinduced changes in plants and soils: linkages to ecosystem functioning in a semi-arid steppe. Funct Ecol 27(1):273-281. https://doi.org/10.1111/13652435.12027

Coutinho ES, Beiroz W, Barbosa M, de Azevedo Xavier JH, Fernandes GW (2019) Arbuscular mycorrhizal fungi in the rhizosphere of saplings used in the restoration of the rupestrian grassland. Ecol Restor 37(3):152-162. https://doi. org/10.3368/er.37.3.152

Delgado-Baquerizo M, Reich PB, Trivedi C, Eldridge DJ, Abades S, Alfaro FD, Bastida F, Berhe AA, Cutler NA, Gallardo A, García-Velázquez L, Hart SC, Hayes PE, He JZ, Hseu ZY, Hu HW, Kirchmair M, Neuhauser S, Pérez CA, Reed SC, Santos F, Sullivan BW, Trivedi P, Wang JT, Weber-Grullon L, Williams MA, Singh BK (2020) Multiple elements of soil biodiversity drive ecosystem functions across biomes. Nat Eol Evol 4(2):210-220. https://doi.org/10.1038/ s41559-019-1084-y

Dong SK, Wen L, Li YY, Wang XX, Zhu L, Li XY (2012) Soil-quality effects of grassland degradation and restoration on the Qinghai-Tibetan Plateau. Soil Sci Soc Am J 76(6):2256-2264. https://doi.org/10.2136/sssaj2012.0092.

Du XF, Li YB, Han X, Ahmad W, Li Q (2020) Using high-throughput sequencing quantitatively to investigate soil nematode community composition in a steppe-forest ecotone. Appl Soil Ecol 152:103562. https://doi.org/10.1016/j. apsoil.2020.103562

Ferris H, Bongers T, de Goede RGM (2001) A framework for soil food web diagnostics: extension of the nematode faunal analysis concept. Appl Soil Ecol 18(1):13-29. https://doi.org/10.1016/S0929-1393(01)00152-4

Gaitán JJ, Bran DE, Oliva GE, Aguiar MR, Buono GG, Ferrante D, Nakamatsu V, Ciari G, Salomone JM, Massara V, Martínez GG, Maestre FT (2018) Aridity and overgrazing have convergent effects on ecosystem structure and functioning in patagonian rangelands. Land Degrad Dev 29(2):210-218. https://doi.org/ $10.1002 / \mathrm{dr} .2694$

Gang CC, Zhou W, Chen YZ, Wang ZQ, Sun ZG, Li JL, Qi JG, Odeh I (2014) Quantitative assessment of the contributions of climate change and human activities on global grassland degradation. Environ Earth Sci 72(11):42734282. https://doi.org/10.1007/s12665-014-3322-6

Gao YZ, Giese M, Lin S, Sattelmacher B, Zhao Y, Brueck H (2008) Belowground net primary productivity and biomass allocation of a grassland in Inner Mongolia is affected by grazing intensity. Plant Soil 307(1-2):41-50. https:// doi.org/10.1007/s11104-008-9579-3

Guo SJ, Han XH, Li H, Wang T, Tong XG, Ren GX, Feng YZ, Yang GH (2018) Evaluation of soil quality along two revegetation chronosequences on the Loess Hilly Region of China. Sci Total Environ 633:808-815. https://doi.org/10. 1016/j.scitotenv.2018.03.210 
He SY, Richards K (2015) Impact of meadow degradation on soil water status and pasture management - a case study in Tibet. Land Degrad Dev 26(5):468479. https://doi.org/10.1002/ldr.2358

Hendricks HH, Bond WJ, Midgley JJ, Novellie PA (2005) Plant species richness and composition a long livestock grazing intensity gradients in a Namaqualand (South Africa) protected area. Plant Ecol 176(1):19-33. https://doi.org/10. 1007/s11258-003-0009-6

Hu ZM, Li SG, Guo Q, Niu SL, He NP, Li LH, Yu GR (2016) A synthesis of the effect of grazing exclusion on carbon dynamics in grasslands in China. Global Change Biol 22(4):1385-1393. https://doi.org/10.1111/gcb.13133

IUSS Working Group WRB (2006) World reference base for soil resources 2006. FAO, Rome World Soil Resources Reports No. 103

Karlen DL, Ditzler CA, Andrews SS (2003) Soil quality: why and how? Geoderma 114(3-4):145-156. https://doi.org/10.1016/s0016-7061(03)00039-9

Kim HT (1998) Soil reaction. Principles of Soil Chemistry. CRC Press, New York

Lal R (2015) Restoring soil quality to mitigate soil degradation. Sustainability 7(5): 5875-5895. https://doi.org/10.3390/su7055875

Li Q, Liang WJ, Zhang XK, Mahamood M (2017) Soil nematodes of grasslands in Northern China. Elsevier, San Diego

Li W, Wang JL, Zhang XJ, Shi SL, Cao WX (2018) Effect of degradation and rebuilding of artificial grasslands on soil respiration and carbon and nitrogen pools on an alpine meadow of the Qinghai-Tibetan Plateau. Ecol Eng 111: 134-142. https://doi.org/10.1016/j.ecoleng.2017.10.013

Li YB, Liang SW, Du XF, Kou XC, Lv XT, Li Q (2020) Mowing did not mitigate the negative effects of nitrogen deposition on soil nematode community in a temperate steppe. Soil Ecol Lett. https://doi.org/10.1007/s42832-020-0048-0

Li YY, Dong SK, Wen L, Wang XX, Wu Y (2013) Assessing the soil quality of alpine grasslands in the Qinghai-Tibetan Plateau using a modified soil quality index. Environ Monit Assess 185(10):8011-8022. https://doi.org/10.1007/s10661-013$3151-1$

Lin B, Zhao XR, Zheng Y, Qi S, Liu XZ (2017) Effect of grazing intensity on protozoan community, microbial biomass, and enzyme activity in an alpine meadow on the Tibetan Plateau. J Soil Sediment 17(12):2752-2762. https:// doi.org/10.1007/s11368-017-1695-3

Lü XT, Reed S, Hou SL, Hu YY, Wei HW, Lü FM, Cui Q, Han XG (2017) Temporal variability of foliar nutrients: responses to nitrogen deposition and prescribed fire in a temperate steppe. Biogeochemistry 133(3):295-305. https://doi.org/ 10.1007/s10533-017-0333-x

Lyu X, Li XB, Gong JR, Wang H, Dang DL, Dou HS, Li SK, Liu SY (2020) Comprehensive grassland degradation monitoring by remote sensing in Xilinhot, Inner Mongolia, China. Sustainability 12(9):3682. https://doi.org/10. 3390/su12093682

Mahaming AR, Mills AAS, Adl SM (2009) Soil community changes during secondary succession to naturalized grasslands. Appl Soil Ecol 41(2):137-147. https://doi.org/10.1016/j.apsoil.2008.11.003

McSherry ME, Ritchie ME (2013) Effects of grazing on grassland soil carbon: a global review. Global Change Biol 19(5):1347-1357. https://doi.org/10.1111/ gcb. 12144

Mikola J, Setälä H, Virkajärvi P, Saarijärvi K, Ilmarinen K, Voigt W, Vestberg M (2009) Defoliation and patchy nutrient return drive grazing effects on plant and soil properties in a dairy cow pasture. Ecol Monogr 79(2):221-244. https://doi. org/10.1890/08-1846.1

Oostenbrink M (1960) Estimating nematode populations by some selected methods. Nematology, Chapel Hill

Penner JF, Frank DA (2019) Litter decomposition in Yellowstone grasslands: the roles of large herbivores, litter quality, and climate. Ecosystems 22(4):929-937. https://doi.org/10.1007/s10021-018-0310-9

Qi JG, Chen JQ, Wan SQ, Ai LK (2012) Understanding the coupled natural and human systems in Dryland East Asia. Environ Res Lett 7(1):015202. https://doi. org/10.1088/1748-9326/7/1/015202

Qi S, Zheng HX, Lin QM, Li GT, Xi ZH, Zhao XR (2011) Effects of livestock grazing intensity on soil biota in a semiarid steppe of Inner Mongolia. Plant Soil 340(1-2):117-126. https://doi.org/10.1007/s11104-010-0463-6

Raiesi F, Salek-Gilani S (2020) Development of a soil quality index for characterizing effects of land-use changes on degradation and ecological restoration of rangeland soils in a semi-arid ecosystem. Land Degrad Dev 31(12):1533-1544. https://doi.org/10.1002/ldr.3553

Ren JZ, Hu ZZ, Zhao J, Zhang DG, Hou FJ, Lin HL, Mu XD (2008) A grassland classification system and its application in China. Rangeland J 30(2):199-209. https://doi.org/10.1071/rj08002
Ruan WB, Sang Y, Chen Q, Zhu X, Lin S, Gao YB (2012) The response of soil nematode community to nitrogen, water, and grazing history in the Inner Mongolian steppe, China. Ecosystems 15(7):1121-1133. https://doi.org/10. 1007/s10021-012-9570-y

Shen X, Yang F, Xiao CW, Zhou Y (2020) Increased contribution of root exudates to soil carbon input during grassland degradation. Soil Biol Biochem 146: 107817. https://doi.org/10.1016/j.soilbio.2020.107817

Six J, Frey SD, Thiet RK, Batten KM (2006) Bacterial and fungal contributions to carbon sequestration in agroecosystems. Soil Sci Soc Am J 70(2):555-569. https://doi.org/10.2136/sssaj2004.0347

Sottile GD, Meretta PE, Tonello MS, Bianchi MM, Mancini MM (2015) Disturbance induced changes in species and functional diversity in southern Patagonian forest-steppe ecotone. Forest Ecol Manag 353:77-86. https://doi.org/10.1016/ j.foreco.2015.05.025

Stone D, Costa D, Daniell TJ, Mitchell SM, Topp CFE, Griffiths BS (2016) Using nematode communities to test a European scale soil biological monitoring programme for policy development. Appl Soil Ecol 97:78-85. https://doi.org/ 10.1016/j.apsoil.2015.08.017

Strickland MS, Rousk J (2010) Considering fungal:bacterial dominance in soils methods, controls, and ecosystem implications. Soil Biol Biochem 42(9):13851395. https://doi.org/10.1016/j.soilbio.2010.05.007

Thakur MP, Reich PB, Fisichelli NA, Stefanski A, Cesarz S, Dobies T, Rich RL, Hobbie SE, Eisenhauer N (2014) Nematode community shifts in response to experimental warming and canopy conditions are associated with plant community changes in the temperate-boreal forest ecotone. Oecologia 175(2):713-723. https://doi.org/10.1007/s00442-014-2927-5

Townshend JL (1963) A modification and evaluation of the apparatus for the Oostenbrink direct cotton wool filter extraction method. Nematologica 9 : 106-110. https://doi.org/10.1163/187529263X00205

Wang XT, Nielsen UN, Yang XL, Zhang LM, Zhou XH, Du GZ, Li GX, Chen SY, Xiao $S$ (2018) Grazing induces direct and indirect shrub effects on soil nematode communities. Soil Biol Biochem 121:193-201. https://doi.org/10.1016/j.soilbio. 2018.03.007

Waring BG, Averill C, Hawkes CV (2013) Differences in fungal and bacterial physiology alter soil carbon and nitrogen cycling: insights from meta-analysis and theoretical models. Ecol Lett 16(7):887-894. https://doi.org/10.1111/ele.12125

Wilson CH, Strickland MS, Hutchings JA, Bianchi TS, Flory SL (2018) Grazing enhances belowground carbon allocation, microbial biomass, and soil carbon in a subtropical grassland. Global Change Biol 24(7):2997-3009. https://doi.org/10.1111/gcb.14070

Wu GL, Ren GH, Dong QM, Shi JJ, Wang YL (2014) Above- and belowground response along degradation gradient in an alpine grassland of the QinghaiTibetan Plateau. Clean-Soil Air Water 42(3):319-323. https://doi.org/10.1002/ clen.201200084

Xiong D, Wei CZ, Wubs ERJ, Veen GJ, Liang WJ, Wang XB, Li Q, Van der Putten WH, Han XG (2020) Nonlinear responses of soil nematode community composition to increasing aridity. Global Ecol Biogeogr 29(1):117-126. https://doi.org/10.1111/geb.13013

Xu DW, Chen BR, Yan RR, Yan YC, Sun XB, Xu LJ, Xin XP (2019) Quantitative monitoring of grazing intensity in the temperate meadow steppe based on remote sensing data. Int J Remote Sens 40(5-6):2227-2242. https://doi.org/10. 1080/01431161.2018.1500733

Yan L, Li Y, Wang L, Zhang XD, Wang JZ, Wu HD, Yan ZQ, Zhang KR, Kang XM (2020) Grazing significantly increases root shoot ratio but decreases soil organic carbon in Qinghai-Tibetan Plateau grasslands: a hierarchical metaanalysis. Land Degrad Dev 31:2369-2378. https://doi.org/10.1002/ldr.3606

Yan RR, Tang HJ, Xin XP, Chen BR, Murray PJ, Yan YC, Wang X, Yang GX (2016) Grazing intensity and driving factors affect soil nitrous oxide fluxes during the growing seasons in the Hulunber meadow steppe of China. Environ Res Lett 11(5):054004. https://doi.org/10.1088/1748-9326/11/5/054004

Yang GJ, Lü XT, Stevens CJ, Zhang GM, Wang HY, Wang ZW, Zhang ZJ, Liu ZY, Han XG (2019) Mowing mitigates the negative impacts of $\mathrm{N}$ addition on plant species diversity. Oecologia 189(3):769-779. https://doi.org/10.1007/ s00442-019-04353-9

Yeates GW, Bongers T, de Goede RGM, Freckman DW, Georgieva SS (1993) Feeding habits in soil nematode families and genera - an outline for soil ecologists. J Nematol 25(3):315-331

Zhang YH, Xu XL, Li ZW, Liu MX, Xu CH, Zhang RF, Luo W (2019) Effects of vegetation restoration on soil quality in degraded karst landscapes of southwest China. Sci Total Environ 650:2657-2665. https://doi.org/10.1016/j. scitotenv.2018.09.372 
Zhou H, Zhang DG, Jiang ZH, Sun P, Xiao HL, Wu YX, Chen JG (2019) Changes in the soil microbial communities of alpine steppe at Qinghai-Tibetan Plateau under different degradation levels. Sci Total Environ 651:2281-2291. https:// doi.org/10.1016/i.scitotenv.2018.09.336

Zhu XY, Gao BJ, Yuan SL, Hu YC (2010) Community structure and seasonal variation of soil arthropods in the forest-steppe ecotone of the mountainous region in Northern Hebei, China. J Mt Sci-Engl 7(2):187-196. https://doi.org/ 10.1007/s11629-010-0198-0

\section{Publisher's Note}

Springer Nature remains neutral with regard to jurisdictional claims in published maps and institutional affiliations.

\section{Submit your manuscript to a SpringerOpen ${ }^{\circ}$ journal and benefit from:}

- Convenient online submission

- Rigorous peer review

- Open access: articles freely available online

High visibility within the field

- Retaining the copyright to your article

Submit your next manuscript at $\boldsymbol{\nabla}$ springeropen.com 